\title{
Speed Gradient Control Algorithm for Optogenetic Modeling
}

\author{
Sergey Borisenok ${ }^{1,2^{*}}$ \\ 1* Abdullah Gül University, Faculty of Engineering, Departmant of Electrical and Electronics Engineering, \\ Kayseri, Turkey, (ORCID: 0000-0002-1992-628X), sergey.borisenok@agu.edu.tr \\ ${ }^{2}$ Boğaziçi University, Feza Gürsey Center for Physics and Mathematics, İstanbul, Turkey, (0000-0002-1992-628X), borisenok@gmail.com
}

(1st International Conference on Applied Engineering and Natural Sciences ICAENS 2021, November 1-3, 2021)

(DOI: 10.31590/ejosat.1011271)

ATIF/REFERENCE: Borisenok, S. (2021). Speed Gradient Control Algorithm for Optogenetic Modeling. European Journal of Science and Technology, (28), 771-774.

\begin{abstract}
We discuss the feedback algorithm for the optogenetic control over the membrane conductance in the frame of Grossman-NikolicToumazou-Degenaar (GNTD) ordinary differential system modeling the response of channelrhodopsin-2 (ChR2) expressing neurons to the light stimulation with the various types of ChR2 mutants. The GNTD population dynamics contains four functional states (two open and two closed) with the transitions among them due to photo-excitations with the stimulating light or decays back from the open to the closed states. The control signal in the model is defined via the photon flux per one ChR2 in the dimensionless form. The control goal is the total conductance of a neural section due to ChR2. We formulate the control algorithm in the form of Fradkov's speed gradient method driving the dynamical system in the phase space such that the target function for the discrepancy between the actual total conductance and its desired level is minimized. We derive the explicit equation for the photon flux field stabilizing the conductance characteristics and perform the numerical simulation for the controlled GNTD differential system to prove the achievability of the control goal. Our approach can be useful for modeling different experimental problems of optogenetics, particularly, for driving the collective dynamics of neural cells in epilepsy, depression, and tumors of the central nervous system.
\end{abstract}

Keywords: Optogenetics, ChR2 channel, Membrane conductance, Feedback control, Speed gradient algorithm.

\section{Optogenetik Modelleşme için Hızlı Gradyan Kontrol Algoritması}

$\ddot{O} \mathbf{z}$

Channelrhodopsin-2'yi (ChR2) ekspres eden nöronların, ChR2 mutantlarının çeşitli tipleriyle ışık uyarımına cevabını modelleyen Grossman-Nikolic-Toumazou-Degenaar (GNTD) sıradan diferansiyel sistemi çerçevesinde zar iletkenliği üzerindeki optogenetik kontrol için geri besleme algoritmasını tartı̧ıyoruz. GNTD popülasyon dinamiği, aralarında geçiş yapabilen ikisi açık ve ikisi kapalı olmak üzere dört işlevsel durum içermektedir. Bu geçişler, uyaran ışı̆̆ın fotoeksitasyonları ya da açık durumlardan kapalı durumlara geri bozulmalar nedeniyle gerçekleşmektedir. Model içindeki kontrol sinyali, boyutsuz şekilde, ChR2 başına foton akısı üzerinden tanımlanmaktadır. Kontrolün amacı ChR2 nedeniyle bir nöral kısmın toplam iletkenliğidir. Var olan toplam iletkenlik ve bu iletkenliğin istenen seviyesi arasındaki uyuşmazlığı temsil eden hedef fonksiyonunun en aza indirilmesi sağlanacak şekilde, faz uzayı içindeki dinamik sistemi yönlendiren Fradkov'un hızlı gradyan yöntemi biçimindeki kontrol algoritmasını formülleştirmekteyiz. İletkenlik özelliklerini kararlı hale getiren foton akı alanı için açık denklemi türetmekte ve kontrol amacına ulaşabilirliğin kanıtı olarak kontrol altındaki GNTD diferansiyel sistemi için sayısal benzetim gerçekleştirmekteyiz. Yaklaşımımız optogenetiğin farklı deneysel problemlerini modellemede, özellikle, epilepsi, depresyon ve merkezi sinir sistemi tümörlerindeki sinir hücrelerinin toplu dinamiğini yönlendirmede faydalı olabilmektedir.

Anahtar Kelimeler: Optogenetik, ChR2 kanal1, Membran iletkenliği, Geribesleme kontrolü, Hızlıgradyan algoritması.

${ }^{*}$ CorrespondingAuthor: $\underline{\text { sergey.borisenok@agu.edu.tr }}$ 


\section{Introduction}

Last decade the genetic engineering methods have been applied to excite or inhibit single neurons and their populations via light-sensitive channels with different optical devices.

Optogenetics serves as an alternative to electrical stimulation for the control over the membrane voltage, and for the modification of action potentials in excitable cells (Williams and Entcheva, 2015). It is superior to classical activation by microelectrodes. The reason for this is its high temporal and spatial resolution. Optical stimulation can be achieved by using caged compounds, e.g. caged ATP, caged Glutamate, whereby the substrates for depolarizing ion channels are delivered to membranes and activated by pulses of UV-light to the chemical photolabile cage in the micro- and millisecond time scale.

Optogenetics allows neurons to be controlled with millisecond pulses through the light-driven activation or inactivation of the light-gated ion channels such as Channelrhodopsin-2 (ChR2) or pumps such as Halorhodopsin.

Optogenetics has many applications, for instance, it allows controlling functions of neural cells in epilepsy, depression, and tumors of the central nervous system (Camporeze et al., 2018). Optogenetic data can be very useful for reconstructing dynamical models of brain dynamics (Oprisan et al., 2015) and for imaging and manipulating brain networks (Forli et al., 2021). Together with electrophysiological data, it provides the selfassembled multifunctional neural probes as a powerful tool for investigating causal relationships between neural circuit activity and function (Zou et al., 2021).

Here we discuss the feedback speed gradient algorithmbased model for control over the membrane conductance in the frame of the Grossman-Nikolic-Toumazou-Degenaar ordinary differential system.

\section{Control Model for Optogenetics}

As a basic approach for control algorithms for optogenetics, we chose here the Grossman-Nikolic-Toumazou-Degenaar (GNTD) model (Grossman et al., 2011) for the response of channelrhodopsin-2 (ChR2) expressing neurons to the light stimulation using various types of ChR2 mutants which follows the research (Nagel et al., 2003; Hegemann et al., 2005).

\subsection{Grossman-Nikolic-Toumazou-DegenaarModel}

The GNTD model describes two open ( $O 1$ and $O 2)$ and two closed ( $C 1$ and $C 2$ ) functional states, which do not necessarily represent the actual energy states of ChR2 (Grossman et al., 2011), see Fig.1.

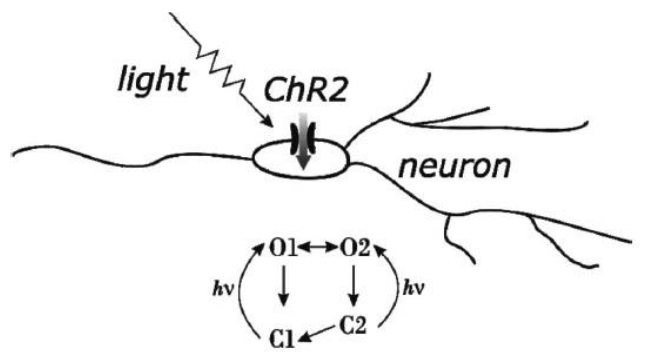

Figure 1.The scheme for the interaction of ChR2 expressing neuron with the stimulating light (Grossman et al., 2011).
ChR2 neuron can be photo-excited from its $C 1$ dark-adapted closed state to any open state. From an excited state $O 1$, ChR2 either decays back to the closed state $C 1$ or converts into a different open state $O 2$. The state $O 2$ is supposed to be less conductive but more stable in comparison to $O 1$. The transition from $O 1$ to $O 2$ can be both thermal and pulsed light stimuli into $\mathrm{ChR} 2$ current. Then from the open state $O 2, \mathrm{ChR} 2$ either decays to another close state $C 2$ or converts back to the open state $O 1$, again by thermal or light excitation. From the state $C 2$, ChR2 can be photo-excited back to $O 2$ or slowly converted (only thermally) to $C 1$.

The total number Nof ChR2s in a cell section is constant:

$$
N_{C 1}+N_{C 2}+N_{O 1}+N_{O 2}=N=\text { const. }
$$

The population dynamics of these states can be described as the system of the following three differential equations:

$$
\begin{aligned}
& \frac{d N_{O 1}}{d t}=K_{a 1} N_{C 1}-\left(K_{d 1}+e_{12}\right) N_{O 1}+e_{21} N_{O 2} ; \\
& \frac{d N_{O 2}}{d t}=K_{a 2} N_{C 2}+e_{12} N_{O 1}-\left(K_{d 2}+e_{21}\right) N_{O 2} ; \\
& \frac{d N_{C 2}}{d t}=K_{d 2} N_{O 2}-\left(K_{a 2}+K_{r}\right) N_{C 2} .
\end{aligned}
$$

Here the parameters $K_{d 1}$ and $K_{d 2}$ are the closing rates $O 1 \rightarrow C 1$ and $O 2 \rightarrow C 2$, respectively; $K_{r}$ is the thermal recovery rate $C 2 \rightarrow C 1$. The values $e_{12}$ and $e_{21}$ are the rates of transition between $O 1$ to $O 2$ and vice versa. The parameters $K_{a 1}$ and $K_{a 2}$ are the activation rates $C 1 \rightarrow O 1$ and $C 2 \rightarrow O 2$, respectively.

The set of control parameters in the model (2) is defined via the photon flux $\varphi(t)$ per one ChR2 as (Grossman et al., 2011):

$$
K_{a i}=\varepsilon_{i} \varphi(t) ; i=1,2,
$$

where $\varepsilon_{i}$ is the quantum efficiency in the state $C_{i}$ (where $i=1,2$ ).

The total conductance $G_{\mathrm{ChR}}$ of a neural section due to ChR2 is given by:

$$
G_{\mathrm{ChR}}=\left(g_{O 1} N_{O 1}+g_{O 2} N_{O 2}\right) \cdot \frac{1-\exp \left\{-U / U_{0}\right\}}{U / U_{1}},
$$

where $g_{O 1}$ and $g_{O 2}$ are the conductance of the open states $O 1$ and $O 2$, respectively. Eq.(4) considers the dependence of ChR2 conductance on the absolute trans-membrane potential $U$, while $U_{0}$ and $U_{1}$ are empirical constants.

The response of the $n$-th section of a cell to the change in membrane conductance can be then described by the following partial differential equation:

$$
\begin{aligned}
& C \frac{\partial V_{n}}{\partial t}=-\left[I_{\text {ionic }}^{n}+G_{\mathrm{ChR}}^{n}(\varphi, U) U_{n}+\right. \\
& \left.+\gamma_{n-1}^{n}\left(V_{n}-V_{n-1}\right)+\gamma_{n+1}^{n}\left(V_{n}-V_{n+1}\right)\right] .
\end{aligned}
$$

Here, $I_{\text {ionic }}$ denotes the current through the native ion channels, $C$ is the cell section capacitance, and $V$ is the membrane potential relative to rest potential $V_{\text {rest }}\left(U=V-V_{\text {rest }} ; V_{\text {rest }}=-70 \mathrm{mV}\right)$. The parameters $\gamma_{n}$ and $\gamma_{n-1}$ are the conductances between the two neighboring compartments.

The model (5) assumes that the extracellular potential that is produced by the certain neuron's own activity is negligible. 
Thus, the intracellular potential is set equal to the transmembrane potential.

\subsection{Speed Gradient Control Algorithm for the Membrane Conductance}

To control the response of the $n$-th section of a cell to the change in membrane conductance (5), one needs to handle the total conductance $G_{\mathrm{ChR}}$ (4) of a neural section due to ChR2, including the factor

$$
f=g_{O 1} N_{O 1}+g_{O 2} N_{O 2} .
$$
level:

For the purpose of stabilization of (6) at the certain target

$$
f_{*}=g_{O 1} N_{O 1^{*}}+g_{O 2} N_{O 2^{*}},
$$

we consider here the feedback speed gradient algorithm (Fradkov, 2007). Let's define the target non-negative function:

$$
G=\frac{1}{2}\left(f-f_{*}\right)^{2} .
$$

Minimization of function (8) corresponds to the achievement of the control goal (7). This goal is provided by the gradient $\nabla_{\varphi}$ in the space of the control parameter (3):

$$
\varphi(t)=-\Gamma \nabla_{\varphi}\left(\frac{d G}{d t}\right)=-\Gamma \frac{\partial}{\partial \varphi}\left(\frac{d G}{d t}\right) .
$$

Here $\Gamma$ is a positive constant with the dimension of the inverse time. The control signal in (3) is one-dimensional; therefore the gradient in (9) is reduced to the partial derivative.

By the application of (9) to the target function (7)-(8):

$$
\frac{d G}{d T}=\left(f-f_{*}\right) \cdot\left(g_{O 1} \frac{d N_{O 1}}{d t}+g_{O 2} \frac{d N_{O 2}}{d t}\right),
$$

and, by the substitution (2) into RHS(10), one obtains the control signal in the form:

$$
\begin{aligned}
& \varphi=-\Gamma \cdot\left[g_{01}\left(N_{O 1}-N_{O 1^{*}}\right)+g_{O 2}\left(N_{O 2}-N_{O 2^{*}}\right)\right] \times \\
& \times\left[g_{O 1} \varepsilon_{1}\left(N-N_{O 1}-N_{O 2}-N_{C 2}\right)+g_{O 2} \varepsilon_{2} N_{C 2}\right] .
\end{aligned}
$$

We considered in (11) property (1) for $N_{C 1}$.

\section{Numerical Simulations}

The set of the GNTD model constant parameters is given in Table 1.

Table 1.Set of the GNTD model constant parameters

\begin{tabular}{|c|c|c|}
\hline Parameter & Value & Unit \\
\hline$\varepsilon_{1}$ & 0.5 & $\mathrm{~ms}^{-1}$ \\
\hline$\varepsilon_{2}$ & 0.12 & $\mathrm{~ms}^{-1}$ \\
\hline$K_{d 1}$ & 0.1 & $\mathrm{~ms}^{-1}$ \\
\hline$K_{d 2}$ & 0.05 & $\mathrm{~ms}^{-1}$ \\
\hline$K_{r}$ & 0.0003 & $\mathrm{~ms}^{-1}$ \\
\hline$e_{12}$ & 0.011 & $\mathrm{~ms}^{-1}$ \\
\hline$e_{21}$ & 0.008 & $\mathrm{~ms}^{-1}$ \\
\hline$g_{O 1}$ & 20 & $\mathrm{nS}$ \\
\hline$g_{O 2}$ & 10 & $\mathrm{nS}$ \\
\hline$U_{0}$ & 40 & $\mathrm{mV}$ \\
\hline$U_{1}$ & 15 & $\mathrm{mV}$ \\
\hline
\end{tabular}

For our numerical simulations, we followed (Grossman et al., 2011) for the following numerical parameter set. The conductances of the open states $g_{\mathrm{O} 1}$ and $g_{\mathrm{O} 2}$ are chosen according to (Hegemann et al., 2005). All inverse time scales, including the constant $\Gamma$, are taken in $\mathrm{ms}^{-1}$, the conductances - in $\mathrm{nS}$, the voltages - in $\mathrm{mV}$.

The results of the numerical simulations for the model developed here are represented in Figure 2.The set of initial conditions is: $N=10, N_{C 1}=10, N_{C 2}=0, N_{O 1}=0, N_{O 2}=0$; the target populations for the open states are: $N_{O 1^{*}}=0, N_{O 2^{*}}=10$, i.e. all population from the initial closed state $N_{C 1}$ should be transferred to the open state $N_{O 2}$. The speed gradient control constant is chosen as: $\Gamma=10$.

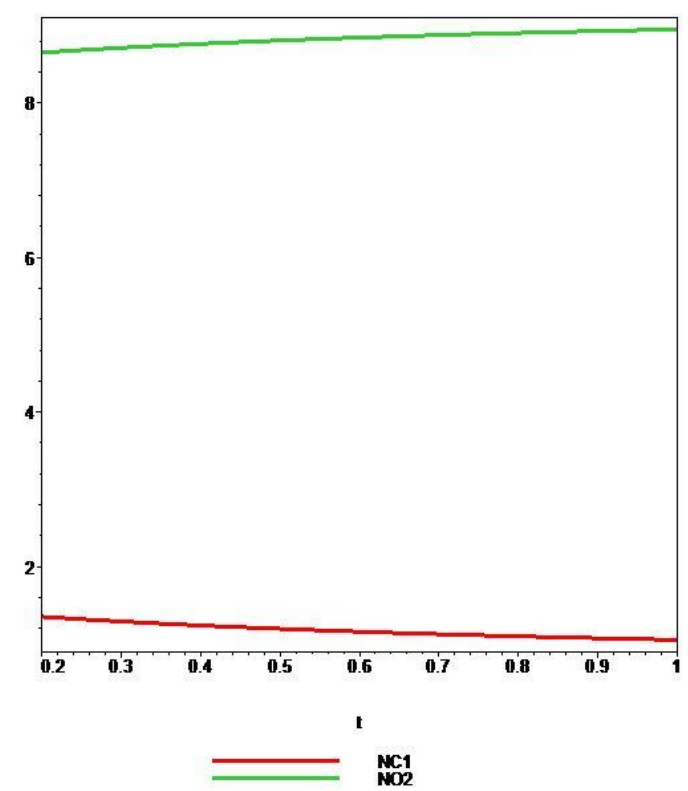

Figure 2.Numerical simulations for the speed gradient control over the total conductance (4): $N_{C 1}(t)$ (red) and $N_{O 2}(t)$ (green).The time scale for $t$ is given in $\mathrm{ms}$.

As in general, the speed gradient method provides the numerical convergence of the set of variables to their target values almost exponentially with a certain error.

The numerical simulations in Fig.2 demonstrate the achievability of the control goal (7)-(8). Indeed, with the very basic qualitative analysis of the numerical parameters for the system (2) based on the Table 1 we can neglect the second and third terns in RHS(2) of first two equations and consider $N_{C 2}$ to be virtually a constant (the corresponding coefficients in RHS have the smaller scales).

That simplifies our system, and for the first two dynamical equations we obtain:

$$
\begin{aligned}
\frac{d N_{O 1}}{d t} \approx & -\left(10-N_{O 1}-N_{O 2}\right) \cdot N_{C 1} \times \\
& \times\left[20 N_{O 1}+10\left(N_{O 2}-10\right)\right] \\
\frac{d N_{O 1}}{d t} \approx & -1.2 \cdot\left(10-N_{O 1}-N_{O 2}\right) \cdot N_{C 2} \times \\
\times & \times\left[20 N_{O 1}+10\left(N_{O 2}-10\right)\right] .
\end{aligned}
$$

By (12), as soon as the control goal is achieved $\left(N_{O 1}=0\right.$ and $\left.N_{O 2}=10\right)$, the control becomes switched off. 
We should emphasize here that Fradkov's speed gradient method is robust with respect to relatively small external perturbations and noise; it is not very sensitive to the choice of the initial conditions for the system (2).

\section{Discussion}

The numerical simulations presented in Fig. 2 prove the efficiency of the proposed algorithm. The control signal (11) does not demand a distinct energy pumping into the system, and it is easy to see that it becomes 0 , when the goal of control is achieved.

Nevertheless, the speed gradient also has some disadvantages: it may lead to a systematic error in the exact level of the target stabilization due to the dissipation effects under the acting control field. Therefore, for future studies we plan to investigate alternative approaches, for instance, Kolesnikov's target attractor feedback (Kolesnikov, 2013) to compare the pros and cons of different control algorithms.

The algorithm for the stabilization goal can be also extended for the case of tracking, when the target function (7) is timedependent. Thus, our approach allows time-depending changing the populations of $\mathrm{ChR} 2$.

\section{Conclusions}

The proposed control algorithm covers the luck in theoretical non-linear feedback methods to drive the dynamics of ChR2 expressing neuron with the stimulating light. It is simple for the performance of real-time computations and could be easily adapted for different experimental setups.

Our approach can be useful for modeling different experimental problems of optogenetics, particularly, for driving the collective dynamics of neural cells in epilepsy, depression, and tumors of the central nervous system.

\section{References}

Camporeze, B., Manica, B. A., Bonafé, G. A., Ferreira, J. J. C., Diniz, A. L., Parisi de Oliveira, C. T., Mathias Jun., L. R., Pires de Aguiar, P. H., Ortega, M. M. (2018). Optogenetics: the new molecular approach to control functions of neural cells in epilepsy, depression and tumors of the central nervous system, The American Journal of Cancer Research, 8(10), 1900-1918. www.ajcr.us /ISSN:2156-6976/ajcr0085158

Forli, A., Pisoni, M., Printz, Y., Yizhar, O., Fellin, T. (2021). Optogenetic strategies for high-efficiency all-optical interrogation using blue-light-sensitive opsins, eLife, 10, e63359.

doi: 10.7554/eLife.63359

Fradkov, A. L. (2007). Cybernetical Physics: From Control of Chaos to Quantum Control, Berlin, Heidelberg, Germany: Springer-Verlag. www.springer.com/gp/book/9783540462750

Grossman, N., Nikolic, K., Toumazou, C., Degenaar, P. (2011). Modeling study of the light stimulation of a neuron cell with channelrhodopsin-2 mutants, IEEE Transactions on Biomedical Engineering, 58(6), 1742-1751.

doi: 10.1109/TBME.2011.2114883

Hegemann, P., Ehlenbeck, S., Gradmann, D. (2005). Multiple photocycles of channelrhodopsin, Biophyical. Journal, 89, 3911-3918. doi: 10.1529/biophysj.105.069716

Kolesnikov, A. A. (2013). Synergetic Control Methods of Complex Systems, 2nd ed., Moscow: URSS Publ. https://library.bntu.by/sinergeticheskie-metodyupravleniya-slozhnymi-sistemami-energeticheskie-sistemy

Nagel, G., Szellas, T., Huhn, W., Kateriya, S., Adeishvili, N., Berthold, P., Ollig, D., Hegemann, P., Bamberg, E. (2003) Channel-rhodopsin-2, a directly light-gated cation-selective membrane channel, Proceedings of the National Academy of Sciences of the United States of America, 100, 1394013945.

doi: 10.1073/pnas.1936192100

Oprisan, S. A., Lynn, P. E., Tompa, T., Lavin, A. (2015). Reconstructing dynamical models from optogenetic data, BMC Neuroscience, 16, 143.doi: 10.1186/1471-2202-16$\mathrm{S} 1-\mathrm{P} 143$

Williams, J. C., Entcheva, E. (2015). Optogenetic versus electrical stimulation of human cardiomyocytes: Modeling insights, Biophysical Journal, 108, 1934-1945. doi: 10.1016/j.bpj.2015.03.032

Zou, L., Tian, H., Guan, S., Ding, J., Gao, L., Wang, J., Fang, Y. (2021). Self-assembled multifun-ctional neural probes for precise integration of optogenetics and electrophysiology, Nature Communications, 12, 5871. doi: 10.1038/s41467-021-26168-0 